University of Minnesota Morris Digital Well

University of Minnesota Morris Digital Well

Communication, Media, and Rhetoric

Publications

Faculty and Staff Scholarship

6-6-2018

\title{
A Cry and an Outcry: Oplakvane (Complaining) as a Term for Communication Practice
}

Nadezhda Sotirova

University of Minnesota - Morris, nsotirov@morris.umn.edu

Follow this and additional works at: https://digitalcommons.morris.umn.edu/cmr

Part of the Interpersonal and Small Group Communication Commons

\section{Recommended Citation}

Sotirova, N. (2018). A cry and an outcry: Oplakvane (complaining) as a term for communication practice. Journal of International and Intercultural Communication 11(4), 304-323.

This Article is brought to you for free and open access by the Faculty and Staff Scholarship at University of Minnesota Morris Digital Well. It has been accepted for inclusion in Communication, Media, and Rhetoric Publications by an authorized administrator of University of Minnesota Morris Digital Well. For more information, please contact skulann@morris.umn.edu. 


\section{A Cry and an Outcry: Oplakvane (Complaining) as a Term for Communication Practice}

This study examined the term oplakvane in Bulgarian discourse. It refers to a communication practice — similar to complaining — and a range of associated cultural meanings for ways to construct a socio-economic and political reality. Data for this study included naturally occurring talk recorded during social events, interview responses from 50 participants, and a range of media postings from newspapers and online sources. These were examined through the lens of ethnography of communication and studies of terms for talk. By examining the term's context, potency, use, messages, meanings, and enactments, a larger cultural landscape is made available, illustrating how oplakvane not only describes negative talk, but references a communication ritual that serves to: 1) release the frustrations of everyday life, 2) celebrate and reinforce feelings of fate and despair, and 3) identify and locate a national Bulgarian character.

Keywords: ethnography of communication, terms for talk, oplakvane, complaining, cultural communication, griping, national identity, Bulgaria

Nadezhda Sotirova is an Assistant Professor at University of Minnesota Morris. Her research focuses on oplakvane as a communication term and practice, ethnographic studies of national identity within a post-socialist context, and cultural discourse of mobility in Bulgaria. 
Complaining is a widely recognizable communication practice found across a range of contexts, communities, and cultures. However, the types and styles of complaining exhibit and perpetuate different local symbols and meanings that are manifest within a given culture. Examining the nuances in similarities and differences of such practices allows for the creation of a larger taxonomy of speech forms, styles, and actions, as well as a deeper understanding of the many and variegated ways for constituting culture and its practices.

Although there are numerous benefits to approaching the practice of complaining by focusing on its effects, uses, and seeming universality, it would be a mistake to ignore the cultural variability of the practice, and in particular the terms used to identify it. For example, in the English language, complaining can range from formal "complaints," to everyday "whining," and from "protesting" to "grumbling," "carping." Paying close attention to such meta-discourse (Craig, 1999) as meta-language (Jaworski, Coupland, and Galasinki, 2004), and key cultural terms (Wierzbicka, 1997), allows for understanding the numerous ways participants may characterize a communication practice as significant. In earlier work (Sotirova, 2017), I examined how oplakvane (loosely translated as "complaining" and "mourning") was culturally significant, and exhibited a particular ritualized form with the following components:

(1) Initialization: negative evaluation, criticism

(2) Acknowledgement:

- instances of problems connected to the situation in Bulgaria,

- examples of comparing the situation in Bulgaria to other countries in Europe,

(3) Shared fate: negative evaluative conclusion.

This work goes further by examining the role of oplakvane as a ritualized practice within the larger field of communication in Bulgaria; it provides a deeper and more nuanced 
understanding of oplakvane as a term for communication practice. This is examined by posing the following questions:

(1) How is the cultural term for talk, oplakvane, used in social context?

(2) How is the term oplakvane identified as significant? How is the term used to label a communication practice?

(3) What communicative acts, events, or style does oplakvane refer to?

(4) What specific messages and meanings for pragmatic action are active within oplakvane as a practice?

Approaching oplakvane as a cultural term for talk demonstrates how a local term and language is used in social contexts; it illustrates one more example of communication as a culturally situated practice (Philipsen, 1992); it also invites comparative analyses of underlying local meanings about sociality and personhood, while utilizing a metadiscursive theoretical framework. Identifying cultural terms for local indigenous communication practices and their enactments, as embedded within larger notions of who we are, our social world, and relating within that world, provides an invaluable understanding of how people "conceive of and enact communicative conduct" (Philipsen, 2017, p. 366). Approaching oplakvane through this framework highlights it as embedded within a unique, local cultural milieu and illustrates the ways “complaining”, as a form of comunication practice, has particular historical-cultural meanings that map onto distinct cultural notions of identity, membership, and social action.

Two ostensibly different occurrences initially drew my attention to the term oplakvane and its communicative enactments. The first was a study by Krastev et al. (2004), which described "social pessimism" as prevalent in Bulgaria, despite an increase in GDP in the period 1998-2003. They noted that Bulgarians: "sulk at the bottom of the Life Satisfaction table with 
only $31 \%$ of its citizens content with the life they lead. (p. 4)" They also highlighted the concept of "imaginary majorities," where even though $44 \%$ of respondents said they managed to sufficiently cope with life's problems and difficulties, only $17 \%$ said those around them were able to cope. In other words, people were coping but did not perceive others to be doing so. Krastev et al. (2004) concluded their study by claiming: "[p]essimistic talk turns into a socially prestigious position, being a way for those who benefit from the changes to reintegrate into a society which considers itself a loser as a result of those changes. (p. 22)" The second occurrence was when a colleague drew my attention to an online article, "The rich, the poor and Bulgaria" (Annonymus, 2011), describing the connection between wealth and perceived happiness: Bulgaria was among the "unhappiest" places despite poverty being on the decline. So are Bulgarians unhappy? Is Bulgaria a nation of pessimists? From the above study by Krastev et al. (2004) we can see that survey participants said they were not satisfied or happy with their overall wellbeing, even though they conceded that they "manage to cope" with everyday difficulties. Yet they perceived others as unable to cope. Did this study measure Bulgarians' "reality" and their level of satisfaction and perceived happiness? Or did this study measure the degree to which Bulgarians were willing to acknowledge and communicate their satisfaction? One cannot disregard the discursive implications, where a different explanation for the phenomenon of "social pessimism" and "national happiness" is possible, and particularly from the standpoint of communication. Were survey respondents doing something other than "responding to a survey"? If responding to this survey employed the use of a different local communicative practice, what then was the meaning of such talk?

Refocusing the investigation to illuminate the specific discursive forms used within a community as local communal practices, which individuals have access to and use to situate 
themselves within that community (Philipsen, 2002), is a productive endeavor into understanding the context and symbolic worlds that make them possible. Furthermore, examining oplakvane ethnographically through a "terms for talk" framework (see Carbaugh, 1989) offers a way of understanding communication as constituting and performing sensemaking.

Oplakvane and the practice to which it refers to, are widely accessible within and across Bulgaria. The term is used to describe a grievance, a formal complaint, and even whining. However, I draw attention to the term as describing particular enactments with specific functions: letting off steam and frustration, building togetherness, and identifying members in relation to the larger Bulgarian "situation." A larger cultural narrative of "the Bulgarian situation" involving a particular cultural code of a national identity (national "mentality") as an endemic term is often evoked within interactions, and specifically oplakvane. National “mentality" refers to a compilation of behaviors and ways of thinking that have been created over time. The participants explicitly place the spotlight on the "national mentality" by claiming it to be the "reason" for the Bulgarian "situation.". This cultural notion of a "mentality" being "national" highlights the fusion between biology and nationalism.

As such, the "national mentality" is claimed to have developed during the Ottoman rule (1396-1878), further solidified during the decades of communism (1944-1989), the following period of political transition (1990-present), and is responsible for the present day political, economical, and cultural Bulgarian "situation". The mentality is the combination of all "bad" behaviors Bulgarians have accumulated such as: stealing, being corrupt, not following rules, and being aggressive towards one another. I further explore the background, discursive construction of this national myth, and its implications for cultural understandings of action in Sotirova (in press). Most Bulgarians grow up with the narrative of glory of the Bulgarian history pre-Ottoman 
rule, where all that was previously good was corrupted or lost during the Ottoman rule and the socialist influence afterwards.

As such, oplakvane is not merely a practice of complaining as negative talk that expresses dissatisfaction, but also a cultural tool for communication that navigates a larger historical context of cultivated mistrust. Understanding the term's usefulness within Bulgarian discourse highlights the relational and instrumental role of complaining practices, which both bind and distinguish communal members, and navigate a complex cultural terrain with implications for social action.

\section{Theoretical framework and research questions}

Studies of complaining cross-culturally have been approached from various academic disciplines: psychology (Kowalski, 1996), sociology (Alicke et al., 1992), studies of culture (Szymkow, Wojciszke, \& Baryla, 2003; Wojciszke, 2004/2005), as well as interdisciplinary work (Chebat, Kerzazi, and Zourrig, 2010; Au, Buhalis, \& Law, 2014; Chaudhary, 2017). The phenomenon has been examined as both a means to an end within business settings (Garrett \& Meyers, 1996; Baker, Meyer, \& Chebat, 2011) and advertising, as well as a valuable practice on its own (Lee \& Hall, 2009). Research has explored the expressive norms of dissatisfaction and negative views of the world, which are focal for complaining practices, arguing that such dissatisfaction seems to go bidirectionally, where expressed negative affective states may potentially become actual beliefs and statuses (Wojciszke, 2004/2005). One point of agreement across these disciplines is that complaining as a practice rarely has the instrumental function of improving the status quo, and is more often utilized as a self-presentational or relational tool (Alicke et al., 1992; Kowalski, 1996). 
I suggest approaching the notion of "social pessimism" in Bulgaria as one such instance of negative talk performing a cultural function—a discursively constituted cultural reality situated within a particular, historical terrain—one that includes but is not restricted to "mere complaining." Examining the communication that engenders such a phenomenon through the methodological and theoretical lens of Ethnography of Communication (EC), and "terms for talk" (Carbaugh, 1989), provides insights into the deeper historically bound cultural understandings, norms, and premises that guide talk. When utilized in talk and interaction, then, such terms for communication practice play on and make explicit/implicit statements about people's understanding of their own position and relationship to the world around them (Carbaugh, 2007). And as such, when properly enacted, this practice serves a particular cultural function, namely the affirmation and negotiation of a common identity (Philipsen, 1987). This study examines instances of discourse as a way of speaking in Bulgaria that can be described with the term oplakvane (complaining, mourning). Here, "way of speaking" is used per Hymes' (1962) broad definition which allows for approaching the practice as a cultural term, and its enactments.

Hymes (1962) drew attention to the need for the creation of a generalized theory and body of knowledge, or ethnography of communication (EC), which addressed the diversity of speech, communication repertoires, and ways of speaking. This approach examines communication within human life focusing beyond language as a referential code, making sure not to neglect social meanings and uses. According to EC, each community uses distinctive means and meanings of communication. Through focusing on speech as the entrance point within a speech community, this framework attempts to understand speech practices from the natives' point of view. Thus, communication is understood as a "situated accomplishment" 
(Stewart \& Philipsen, 1984). It is about the distinctive communication practices of particular speech communities, as they are creatively shaped within interaction, in situ, and as shaped in particular socio-historic contexts. In other words, EC is what practices say locally and suggest generally about human communication (Carbaugh, 1995).

\section{Terms for talk}

Carbaugh's "terms for talk" findings (1989), which were built on various Ethnography of Communication studies, were an endeavor to create a comprehensive framework that provided a base for studying participant identified significant terms. Such terms, as communicative resources, provide insight into the symbolic worlds and cultural landscape that are creatively evoked and managed through their use in context. Here, the goal is to examine oplakvane as a way of speaking by first approaching it as a significant term for communication practice and investigate what glimpse it provides into participants' cultural world. The "terms for talk" framework has its roots in Cultural Discourse Analysis (CuDA) as a development from within EC, and is designed to examine how communication is shaped as a cultural practice as well as the symbolic meanings imminent in such practices (Carbaugh, 2007).

Both EC and CuDA are based on the initial conceptual framework created by Hymes (1962) where communication is examined for the ways it makes visible specific local symbols, forms, and meanings used by the particular community (Carbaugh \& Hastings, 1992). Investigating cultural terms for talk provides insight into deep, historically and contextually bound moral systems that guide "talk" within a community, and unveils the bigger cultural scenery that is employed in such "talk." Some examples include Baxter's (1993) "talking things through" and "putting it in writing," Hall and Noguchi's kenson (1995), Katriel's dugri (1986) 
and "griping” (1985), Boromisza-Habashi's “hate speech” (2013), Winchatz's jammern (2017), Covarrubias' respeto (2017), and Dori-Hacohen's tokbek (2017).

Identifying Bulgarian oplakvane as a rich cultural term for talk through this framework and highlighting the symbolic meanings it makes relevant provides one more example of communication as an entrance point into cultural conceptions of identity, emotion, relationships, and dwelling, since to "speak, is to speak culturally" (Philipsen, 1987). As I show below, oplakvane differs from other terms, such as "complaining," or other plaintive talk identified in Bulgarian in the sense that it presupposes "real" problems, and an enactment with specific act sequence, which does not require the offering of a solution. Utilizing EC and the "terms for talk" framework offers a deeper insight into what and how linguistic terms are used to create and express social systems of identity, emotion, dwelling and communication (Carbaugh, 1989), and provides for a meta-commentary on social practices (Carbaugh, 2017).

\section{Bulgarian context}

Bulgaria has a rich past (Crampton, 1997): the country was established in 681 and was a prosperous kingdom for many centuries until its fall to the Ottoman Empire in the late 14th century. The following five centuries the country spent under the economic, political, and cultural veil of Turkish rule. In 1908, after years of informal rebellion and the final RussianTurkish war, Bulgaria declared independence only to be "shoved" into Europe, given a constitution, and expected to be culturally renewed. What followed were several socialist and communist experiments, which have very strong socio-economical and cultural ramifications to this day. During the 1900-2012 period Bulgaria has had to move from a primarily agrarian, preindustrial, "dark ages" status to a modern democratic nation, and the country's struggles with finding its identity in this transitional century become apparent within public discourses. The 
cultural understanding and groundwork for incorporating and successful use of democratic terms and ideology is lacking, the socio-economic and political structure of the country has suffered, where even forms of social protest have been a new experience as illustrated by Triffonov (2017).

One cultural ramification from the socialist past is the cultuvated mistrust and division between "us" (those against the Party) and "them" (supporters of the Party). During the socialist period in the country (1947-1989), numerous practices of inappropriate redistribution and "hoarding" of scarce resources developed (Verdery, 1996). As an overseer of the trade union, the Party's influence was constantly felt within the production process, and as such was considered as meddling, disruptive, and unproductive by the workers. This resulted in managers and union officials who took credit for work they were not performing. Verdery (1996) argued that workplace rules and strategies, which were meant to politicize and strengthen the positive image of the Party and its ideology, did the opposite. Thus, socialism managed to create a rift between "us" and "them," between the workers and the Party leaders and representatives.

Reverberations of this way of identifying "us" vs. "them" can be seen directly within enactments of oplakvane, where the practice serves as a cursor to differentiate between "us" and those associated with the Party/socialist background, and thus having the "mentality." This general atmosphere of mistrust, of cultivated suspiciousness towards one another, and of being constantly under scrutiny from the Party provided a rich ground for communication practices such as oplakvane to appear, as a way to manage frustration and identify whom one could trust.

\section{Methodological notes}

This project is based on observations of naturally occurring talk during social events, discussions, and interviews with 50 participants from various locations within Bulgaria (Sofia, 
Duspat, Kalotina, Butan) during the period 2012-2014, as well as my personal experience as a native "oplakvach." I was born and lived in Sofia, Bulgaria, until 2003 when I left in order to pursue my undergraduate degree in the United States. I use the term speech community per Hymes' (1972) delineation: a community that shares at least one common way of speaking (communicative resource). Oplakvane appears to be widely recognizable and understood within a broad range of geographical, generational, and contextual situations: I recorded instances of the practice across a broad range of backgrounds as well as origin. Oplakvane seems to be one of the more common communication practices that participants evoke and utilize in a wide range of settings.

The collected set provided the data base for the analysis of oplakvane as a distinct communicative term, or over 94 hours of naturally occurring talk, comprised of:

- Events at individual households,

- Events at public settings, celebrations,

- Miscellaneous service encounters.

Spontaneous discourse in informal and formal settings was recorded and then examined for instances of oplakvane. The informal settings consisted of interactions "at dinner tables" and included friends, family, and acquaintances, eating several courses accompanied with drinks. Some instances of informal talk occur even at public settings such as an appliances repair shop in a central location in Sofia. Even though some interactions there were primarily formal service encounters, a large segment of informal talk occurred during breaks among the employees. In order to protect the identity of the participants, I utilized a randomly ascribed alphabetic code. In the segments bellow there are interactions involving I., K., A., B., and G. 
Within the specific interactions, the participants come from a variety of economic, age, geographic, and gender backgrounds.

The formal interactions included customers coming to leave or pick up their small appliances, or calling to schedule appointments. The service venue provided access to diverse interactions as primary data, such as customers who came to the office daily and employees conversations, and secondary data in the form of reports of the phenomenon of oplakvane by the participants. Social interaction at all gatherings was audio recorded. I distributed descriptions of my field work and received consent for recording when I first arrived, and proceeded to record as unobtrusively as possible in order to keep the talk as naturally occurring as possible.

The audio recordings of naturally occurring talk were then coded for:

- number of occurrences (instances): initialization

- number of occurrences (instances): acknowledgments

- number of occurrences (instances): shared fate

- duration (number of utterances) of oplakvane once there is acknowledgement

- duration (number of minutes) of oplakvane once there is acknowledgement

- type of interaction: relational closeness of participants (family, friends, acquaintances, strangers)

All data was analyzed ethnographically creating the following layers:

- A description through Hymes' (1962) SPEAKING components; later, during the interviews, the participants were asked about these descriptive nuances, and I, myself, tested their rationale through misuse of the identified components.

- An interpretation of oplakvane as a "term for talk" based on Carbaugh's (1989a) framework. 
The first phase of the analysis led to more focused interviewing and analyses of preliminary findings, which led to an even more focused phase of testing the norms created based on these findings, and so on, thus employing an ethnographic cycle as an analytic process and moved between the data and conceptualization, the emic and the etic.

After examining the numerous instances of spontaneously occurring oplakvane, I revisited the participants with interview questions. These included questions such as what was considered to qualify as oplakvane, instances that the interviewees supplied themselves, expressed attitudes towards oplakvane, toward descriptions of instances that could be labeled as oplakvane, and elicited responses to (in)appropriate uses of the term se oplakva as well as its enactments. Bulgarian was a tool for analyses, where I did the data collection, recording, and analyses in the Bulgarian language, then translated into English afterwards as needed for the reporting of the findings. Transcriptions were created of the interactions, and were then translated into English.

From all the data recorded, I transcribed numerous instances of oplakvane (over 200 pages), however, since I worked in the original language, I translated only pieces used for illustration within the article. Other data recorded was transcribed topically for the purposes of analysis: in a loose CA style when instances of oplakvane were present, content-based for the interviews, and topically for other instances. Translation was created by remaining close to the original literal sentence structure where possible. English idiomatic phrasing was used only if it conveyed better the interactional meaning. In order to achieve this I translated in two steps: the first layer was transcribing the original spoken Bulgarian, the second an English interpretation of Bulgarian words but with Bulgarian syntax, thus improper English syntax, and the third—-the English meaning equivalent (with same word choices but syntax within the English 
standard). For the sake of brevity, only layers one and three are included. Punctuation was used to indicate intonation at the end of the utterances. Intonation within utterances was not indicated on the transcript itself since it was in English and would be confusing but is discussed within the analysis where relevant.

In addition to recordings, I have collected print, online, and video media including:

- Newspaper articles and media content from public broadcast (23 articles).

- bTV broadcast “The Reporters” (Traikova, 2012): available on the television's website archives. bTV "The Reporters" is a special show for in-depth investigation. bTV, or Balkan Television, was the first privately owned national television channel in Bulgaria (first broadcasted in 2000), operated by bTV Media Group, and is considered the Bulgarian television channel with the largest viewing.

- Online content (over 70 items, or a corpus of over 100 pages): Blog posts and their comments, online political articles, Facebook political groups and organizations' posts and caricatures. Online data came from blog posts and their comments available on blog.bg, frognews.bg, and svejo.bg.

All online and media materials were transferred into a word format document and translated into English where the punctuation and formatting was retained.

\section{Analysis}

\section{Overview}

Based on my analysis, oplakvane constitutes about $10-15 \%$ of the naturally occurring talk in the above-mentioned settings. However, what is more interesting is how oplakvane is distributed. My data indicates that oplakvane occurs the same number of times (initiations of the enactment) even when the interaction is brief. In "casual" (brief) encounters, whether the participants were 
close ("family") or not ("acquaintances"), oplakvane was initiated with the same frequency: 05. Also, in such casual interactions, oplakvane — when initiated-lasted barely more than the initiation (amount of time of the enactment): less than one minute. Or, when the encounter was brief, regardless of how close the participants were relationally, oplakvane did occur, but mostly as initiation and 1-2 acknowledgements, rarely continued for a complete enactment of the act sequence.

On the other hand, when the interactions were longer ("meals" were more than three times longer than "casual" encounters), there were more initiations, with 20-30 instances on average. When breaking this down according to how close the participants were relationally, most initiations of oplakvane occurred among interactions/meals with "acquaintances" (30), less —with "family" (24), and least—with "friends" (20). For these "meals," when oplakvane was initiated, the practice was picked up by the other participants, resulting in enactments more often than during "casual" encounters, regardless of the relational closeness. That is, during "meals" (longer interactions) oplakvane was not only initiated more, but also a complete act sequence enactment took place (uptake), where the longest enactments of the practice occurred among "acquaintances," and less_-among "friends" and "family."

\section{Social uses in context}

\section{Description of the term}

As Sotirova (2017) illustrated, the dictionary definition of to se oplakva is "to lament," "to mourn," with focus on "wailing", for instance when used colloquially in "mourning a dead person." There is a plaintive element to the term, an emphasis on mourning loudly, implied crying, and bereavement. For example, "I oplakvam si my days." In such instances, oplakvam 
se/Oplacha se means both (1) voicing suffering, and (2) expressing displeasure, disagreement. Crucial here is the root of the word: plach, "to cry."

\section{The invitation to oplakvane}

First, I address the way oplakvane is used in context by the participants: its potency, prominence, depth of feeling, and accessibility. Participants explained that to se oplakva refers to "sharing of problems and things/people that bother you." They described the "problems" one se oplakva as encompassing instances of everyday issues. Participants explained that "it is not good to se oplakva," where the enactment has a negative connotation and participants considered engaging in oplakvane as futile. Frequently the participants mentioned that they themselves "do not do it often" since it "burdens" them. The only case when it is appropriate to se oplakva is when there is a "good reason," or when there are "substantial problems," that have not been addressed. One participant summarized what such "good reasons" for oplakvane are (Table 1, 1):

[d]issatisfaction with the non-working system, lack of jobs, ineffective state structures and organization, bureaucracy. The abdication of the state from the everyday problems of people. There's no way out of this situation.

Many participants indicated that oplakvane had a very strong potency. As the term means not only "to complain" but also has strong emphasis on the physical outcry and "mourning," it evokes a very strong emotion: one of anguish, torment, and misery. This emotional tonality attached to the term makes labeling it as such by the participants themselves difficult and problematic: based on what the participants described as enactments of oplakvane, they can often be observed enacting the practice. However, the term has such depth of emotion that the participants are wary of linking their communicative actions to such a culturally 
meaningful word. I will explain this conundrum in more detail once I delineate the purpose of the term.

The term is widely acknowledged and utilized across the country, and the participants frequently used the phrase "let me se oplacha to you" as "hear me out, I have some problems to share." Often the phrase is used as an entrance point within conversations after greeting adjacency pairs: participants would engage in oplakvane immediately after a "how are you" by providing an example of problems from their everyday life. I want to highlight here, that such an initiation is not locally and culturally heard as having a formal complaint, or plaintive talk, but is heard as an introduction to a particular act sequence, requiring a proper reciprocation. The phrase is thus used as "hear me out," and marks an unpleasant topic, at which point offering a solution by the respondent is not culturally appropriate.

A deeper local cultural meaning is evoked through the invitation to oplakvane, where "let me se oplacha to you..." as an act is different from "let us se oplachem" as an event. As an act, the term calls for providing specific instances of problems, whereas the event highlights the common function of blowing off steam. This difference stresses the phatic function of the practice when observed as an event and illustrates a rift between dual purposes. When it is viewed as an act, the purpose is to "complain" and get support from those listening. When it is an event, the focus is on its instrumental role of engaging in binding commiseration.

\section{Enactments}

As discussed above, when oplakvane is used, the term is frequently mentioned at the beginning of an interaction, after a greeting adjacency pair. It is used to signal a specific communicative act (sharing of problems and dissatisfaction) in order to account for a kind of action. For instance: "let me se oplacha to you... always problems! I just bought my car and someone 
already dented it." In this instance, the term oplakvane is used to mark the action and indicate what the culturally adequate response is. This is different from saying "the oplakvanij go to him" (all grievances go to him), where the term is used to account for the action of filing a complaint. In this study, I highlight the function of the term as rendering communicative acts meaningful within a particular ritualized form.

The structure of oplakvane, identified by Sotirova (2017), is visible in the following instances (Table 1.2):

yesterday I se oplakah to my friend, about something my husband did that made me angry. She told me not to get angry, and herself se oplaka from her husband

my friend, has the same problems with her mother in law, so in response to my oplakvane, se oplaka herself from her mother in law.

The participants highlighted that the practice of oplakvane incorporated sharing of problems. Another participant mentioned that when oplakvane is performed, the "conclusion is always one-this is how it is in Bulgaria," which alludes to another component of the enactment, or an evaluative concluding statement. This is an explicit reference to the last part in the enactment of oplakvane. It was a common occurrence for the participants to say that they did not se oplakvat and immediately did so afterwards by utilizing the identified act sequence. A participant mentioned that Bulgarians "plachat" (cry) very frequently and used the root of the term oplakvane in order to stress the emotional tone of the practice (Table 1.3):

We cry a lot, really a lot - it's always somebody else's fault, there is always something wrong... Why - maybe it is a leftover from the old system, in which people did not work qualitatively, everyone was stealing anything they could and had no responsibility for 
anything. And now when you have to study and work hard to achieve anything - it is very hard.

Participating and being an audience to enactments of oplakvane is not restricted to friends, family, or colleagues; even strangers are often included. An enactment of oplakvane can even include strangers, since the topics are commonly intelligible and widely accessible, and one can easily connect to others through them. Participants even said that oplakvane was the "national sport" in Bulgaria, emphasizing that its settings were not restricted to the private area but also included public spaces such as the workplace, restaurants and coffee shops, and waiting in line.

Sharing of problems is the core topic of oplakvane: the participants acknowledged that there must be reasons for oplakvane and these reasons were always linked to the Bulgarian "reality" and "situation" (or "how things in Bulgaria are"). However, the participants also emphasized that Bulgarians can se oplakvat on any topic (see Table 1.4):

[Bulgarians se oplakvat] from everything - bad life, from the weather, from the boss, from the wife/husband, from too much work, from lack of work, well from everything. When it is your nature to be a oplakvach [who se oplakva], you always find something for oplakvane

\section{Purpose}

What do the participants see as the end purpose to enacting oplakvane? The participants claimed oplakvane allowed them to "unburden" themselves. They claimed that the "impossible socioeconomic situation," the "reality" in Bulgaria was the main reason for oplakvane, because, as people felt helpless talk became their only means of agency. Participants agreed that one se oplakva when they are dissatisfied, unhappy, and encounter unfairness. They emphasized that 
this "reality" of socio-political and economic dysfunction in Bulgaria "would never change." This "reality," according to the participants, was all "everyday struggles," which included the "non-functioning laws in Bulgaria, the fact that they are created to benefit certain people" due to the corrupt judicial system. This "situation" and "reality" in Bulgaria was described as (Table 1. 5):

a street with no exit. There is no force, that can make those in power chosen by us think more about what they would give, rather than what they can take from the state and the people. [The Bulgarian situation is t]he big stupidity of the Bulgarian people.

The Bulgarian "situation" was also described by the participants as: "chaos"; "a state of nonfunctioning institutions"; chaos in the "governing, existence, and the life of the Bulgarian nation"; a "crisis of the morale, a crisis of the spirit." Some went even further and suggested that there was no solution to the Bulgarian "situation," as it is (Table 1. 6):

[m]ournful, tragic, with no perspective of getting better.

The solution - atomic bomb.

The participants indicated that oplakvane served to: (1) let out frustration and tension from everyday problems, and (2) identify who one can trust as being one of "us" and not part of "the others" (those possessing the "mentality"). If one was to downplay the difficulties or sufferings of the fellow member who se oplakva, by disagreeing or stating that the issue is "not really a problem," this would be interpreted as a rejection of the ritual and the sense of togetherness resulting from its enactment. Such a need for identification and use of a communication practice to differentiate between "us" (lacking the "mentality," needing to 
se oplakva) from "others" (with the "mentality," perceived to be the problem) can be linked back to a general culture of mistrust developed during socialist times.

\section{Interpretation}

\section{Messages and meanings for pragmatic action}

What are some general types of messages as participants labeled their own acts? What are some of the messages and meanings about the practice itself, and literal meanings of messages about this communication? The mode of action, or the prevalent manner for the enactment is a direct act when viewed by the participants as a rule by which one is supposed to se oplakva, and share examples of problems to people close to oneself. However, as an outsider, one notices exactly the opposite: the participants enact the structure of oplakvane without labeling it as such, without recognizing it, and in those cases, the norm is not to give advice. In fact, providing a solution would disrupt the enactment. Or, for those who are close relationally, the request to se oplakva is interpreted as a request for advice, while for those not considered to be of a close relationship, the norm is not to give advice.

The structure of oplakvane appears to have two layers. When it comes to a range of topics, the scope is restricted and fixed as including only certain topics from within the "Bulgarian situation," or introductory/closing evaluation utterances (e.g., "It's scary." "We'll never get better." ). However, the number of acts of oplakvane can be unlimited, or flexible, and depends on the setting and participants. During dinner events, the enactment of oplakvane was cycled up to 25 or more times and the connection between the instances and the Bulgarian “situation" was enacted elaborately by participants to collectively construct a generalized image of the "other" within the interaction. 
The tone of the practice, as the term itself suggests, is "mournful" and alludes to something beyond displeasure-pain. Apart from referring to a formal grievance and complaint, the term oplakvane itself is used for "mourning," bringing to mind wailing, pulling of hair, and tears. This is one of the reasons the term has a negative connotation. It is used for occasions when there is no escape, no way out, no hope.

The practice varies in tone and emotional pitch throughout participants' enactments. Some examples can be observed from dinner events:

- Frustration: during another dinner event, as A. initiated an oplakvane act of sharing a problematic instance, an insider could "hear" her frustration in two ways in the following utterance (Table 1.7):

[B]ut it doesn't matter, doesn't matter, he doesn't care! And [he] says, "big deal. This is a street. I will park wherever I want.”

The way she expressed frustration is through her intonation, where the first part were in a higher pitch, indicating distress.

- Anger: during the evaluating conclusion to an enactment of oplakvane, the anger can be heard in the following lines (Table 1. 8):

B: there isn't, I have to tell you that this ah young people should should should leave this country.

G: ah (agreeing)

B: they shouldn't [stay] here

G: but absolutely be*, but there is nothing to stay [here] for be*! 
B. expressed the opinion that the only solution left for young people in the country was to emigrate. And G. not only agreed but did so in an outburst, where his voice rised, as though he was yelling at her, and used the dialectical particle $b e^{*}$, which again stressed his point.

Norms

So, is oplakvane effective? From participants' perspectives, two points emerge:

(a) Oplakvane as plaintive talk is not good. It is pointless and futile if done by talking about problems that are not "real."

(b) When one se oplakva to share "real" problems, then it is effective, and one is supposed to receive advice.

For participants, oplakvane is perceived to be effective only if employed to handle "real" problems. And here is where a dilemma arises from the clash of cultural norms for enacting oplakvane, evident when elaborating upon earlier work (see Sotirova, 2017):

(1) One should se oplakva only about "real" problems in need of solutions.

(2) Problems are "real" only when they are a part of the "situation."

(3) When there are "real" problems, people should share their plight with friends, family, and even strangers in public.

(4) When told an instance of a "problem," one should offer another in reciprocity.

(5) The problems that arise from the "situation" cannot be solved because they stem from the "mentality."

(6) One should not offer solutions to the said "problems," since there is no real solution.

How do people se oplakvat about things that cannot be solved and legitimize these communicative acts as different from other plaintive talk? Participants expressed that the purpose of oplakvane is not just to find a solution to problems, but was tied to deeper cultural 
functions. This cultural function, similarly to other "complaining" practices, serves to replay and reaffirm togetherness: through enacting oplakvane, the participants are bound within a specific socio-economic context and shared fate of misery, resulting from a particular Ottoman and socialist past. Enacting oplakvane, however, also serves to identify and differentiate between "us" and "them", those without and those with the "mentality". Unless directly asked, participants, however, rarely acknowledge these cultural functions. The practice is effective in reaffirming and managing the individual-community relationship. However, if one judges the practice based on participants' definition as "sharing problems and receiving advice," then it is not successful since it only incorporates problems, and not solutions.

\section{Messages and meanings for sociality}

What metaphorical messages and meanings does oplakvane bring forth socially? What does it tell us about Bulgarian social roles and identities, social relations, and social institutions. The Bulgarian "situation," "mentality," and the cultural notion of social institutions are intricately connected.

On one level, the root of the term, plach, or "cry," calls attention to a deeper understanding of a particular act of "talking"-as a lament, a wail, an outcry. Statements, or premises of belief, value, and cultural understanding available to Bulgarians to make sense of their interconnectedness in the larger cultural environment can be formulated as in the following:

- Bulgarians are connected in a state of socio-political and economic "crisis";

- the "self" is understood as part of the national community, sharing a common "mentality";

- this "situation" is not changing because it is connected to the "mentality"; 
- the Bulgarian "mentality" is a compilation of behaviors and ways of thinking developed during the years of Ottoman occupation, socialism, and the following transition;

- these behaviors and ways of thinking involve stealing and cheating, which have been reinforced for so long that have become a "biological national" trait;

- thus, Bulgarians are forever doomed in a state of "crisis," "chaos" and a "situation with no exit";

- feelings of anger, frustration, and inability to act result from this continuous "crisis";

- only a "real" Bulgarian understands this vicious cycle and the reasons behind it.

Through the enactment of oplakvane, however, a shared sense of doom is reaffirmed and celebrated. Celebrated, because this "doomed" understanding of their dwelling (the country as a whole) has a positive aspect: Bulgarians' are able to survive and adapt, to exist despite the circumstances. The cultural notion of sociality and how all Bulgarians are connected via the "mentality" is constantly recreated, binding Bulgarians from the past into the future. Taking pride in being bound in a common misfortune is reinforced through constant positioning in opposition to the "mentality," which is represented by individuals, social institutions, and the government. Often, participants' oplakvane contain narratives of bureaucrats attempting to ask for a bribe, or not performing their duties. The response to such a narrative is, "I showed them by swindling them back." This reinforces the example by ironically employing the same behaviors, that are part of and constitute the "mentality" that participants find problematic. Participants consider being subjugated within this dysfunctional system as "bad" and "the Bulgarian way"; but the only "appropriate" Bulgarian response is to cheat back.

Messages and meanings about personhood 
The theme of "Bulgarian-ness" is repeated in everyday conversation and interaction, media, and online sources: "the bleak Bulgarian situation, that only Bulgarians could understand." One online post emphasized: “[s]urely you'll say again, that we only se oplakvame and we don't suggest anything, but when we do it, does anyone hear us?." Participants often made statements about personhood directly, as in the example above, and sometimes indirectly, via positioning themselves and their behaviors in relation to the "mentality" through enactments of oplakvane. Such messages highlight a socio-centric view of personhood: placing "Bulgarian-ness" as an aspect of the "mentality," as a shared biological-behavioral hybrid. The data indicated that the loci of motives are relational and a product of a historical context, in which the Bulgarian identity is constantly positioned as a cause and inevitable outcome among forces outside the individual.

The historical roots of such sociation seem to be organic: a historical evolution grand narrative, where "Bulgarian-ness" has developed as a mutation where survival skills, developed during time periods of distress under the Ottoman Empire, and socialist times (Sotirova, in press), have reached a point where they no longer serve the present population. Participants often mentioned biological/cognitive aspects as inseparable from nationality, resulting in the cultural conceptualization of a national character with a very problematic narodopsihologia ("national psychology"). The extreme of how problematic such a national character is can be seen in many concluding evaluation acts of oplakvane: participants often joked that an atomic bomb was the only solution to the "situation" in Bulgaria. But if someone was to drop it, "who knows, Bulgarians are so resilient that they may evolve into something even worse." I have heard this joke repeated many times, implying that Bulgaria as a context, coupled with 
Bulgarians' ability to survive, have mutated to create and perpetuate an incredibly potent national identity—one both despised and revered.

The cultural term oplakvane and the communication practice it refers to not only highlight larger cultural messages of identity, personhood, relations and sociality, but also deeper local messages about dwelling, emotion, and action:

- Identity and personhood: through enactments of oplakvane, a significant cultural understanding of "Bulgarian-ness" as linked to a Bulgarian "mentality," is reconstituted and celebrated. And, one is recognized to have the "mentality" or not, by enacting oplakvane.

- Action and agency: through enactments of oplakvane, a certain type of action (or inaction) is reinforced—nothing will "save" Bulgarians because of the symbiotic connection between the Bulgarian "mentality" and the "situation." And as action is futile, only through oplakvane can anger and frustration be released. One can only se oplakva until waiting for the "situation" to change on its own, as the only possible action is to wait for another "biological" change or mutation. By enacting oplakvane participants perform their only available action.

- Emotion: through enacting oplakvane, feelings of anger, frustration, and resignation are fostered and reinforced through constantly re-playing the Bulgarian "situation." Enacting the practice becomes a lament about a shared fate, or being "stuck" within a vicious cycle.

- Dwelling: through enacting oplakvane, a larger symbolic dwelling is being reinforced-a world of chaos and hopelessness, where nothing works. 
Oplakvane has a purpose of letting out anger and frustration out but, as it builds a sense of togetherness, it is perceived as inevitable, a result of the larger situation. The communicative practice exists in a domain where talk is viewed as a dispreferred social strategy, or an antithesis to social action: "the hen that clucks the most, provides the least eggs," "a word said is a stone thrown," and "whoever is silent, a prettier word says" are famous adages, and illustrate the local cultural value of action over talk. In this case there is no surprise that if talk is not preferred as a social strategy, and gets in the way of social action, then acknowledging that the oplakvane mode is just that (a communication practice serving to let off steam and reinforce togetherness) would reduce the "reality" constructed within that interaction to mere "useless" talk. In this way, oplakvane highlights a tendency of the participants to dramatize major cultural problems within their social environment, and provide a social context and setting for the dealing with feelings of frustration. Understanding how such informal verbal rituals shape the social experience of the individuals participating in them provides further clues to the formation of the cultural reality of social worlds and communal lives.

\section{Conclusion}

When Bulgarians speak, or se oplakvat in particular, they do so from a particular cultural and communal situated-ness. Through such enactments, they identify their individual stances in relation to the larger Bulgarian "situation." Since participants do not perceive oplakvane as a separate self-contained communication practice, it tends to appear at various discursive times, and affects what local conceptualizations of agency are available to participants. While participants acknowledge that oplakvane serves to let out frustration and build a sense of togetherness, it is often perceived as problematic, as it is a result of larger national discontent. 
In this study, I offer a more detailed examination of oplakvane as a cultural term for communication in Bulgarian discourse, expanding on the communicative acts Sotirova (2017) identified, by describing more extensively the term's literal and metaphorical meanings about communication, sociality, and personhood, where a specific national identity is celebrated as well as condemned. This cultural conceptualization of national character is celebrated as an example of Bulgarians' ability to adapt and survive, yet is condemned because it reflects the country's past, where this national identity seems to be firmly lodged. Such an understanding of social roles and identity is particularly visible within oplakvane as a term that encapsulates bemoaning, complaining, grieving, and mourning. The cultural potency of the term also speaks to a particular cultural solidarity—among Bulgarians, who know hardships, and are trapped between "those" with the "mentality," and "those" who consider themselves "almost European," but realize they do not have the cultural understanding, discourse, or a differently conceptualized way of being that would allow them to change. Examining the way communication practices reconstitute social roles and identities as a result of a particular socio-historic context provides not only a methodological and theoretical challenge but also highlights points of self-reflection and intervention.

Oplakvane finds expression in and during dinner events but also in other non-structured situations including small talk. Exactly because it is not recognized as a separate practice, it seeps into other communication modes. This has several implications: unlike other “complaining" practices, i.e. griping (Katriel, 1985), where any attempt at discussing the situation and problems pertaining to it may be labeled as griping and dismissed, oplakvane, even when not easily dismissed, shifts the constructed "reality" within its enactments creating a 
paradox. The communication practice highlights how "bad" things are in Bulgaria, yet the participants are aware that enacting it is only meant to let off steam.

So which is it? Is it just talk for solidarity or a cry for help? As discourse serves to position us within particular cultural spaces, it also allows and restricts particular action. It reaffirms the culture-scape we navigate in order to make not only our actions but also the actions of others coherent and legitimate. Understanding oplakvane as a cultural term for communication and a communication practice presents an interesting theoretical challenge as explicit labeling of the practice with the term shifts and questions the participants' cultural realities. Acknowledging the enactments as oplakvane renders the talk "only" a ritual for the participants, causing the carefully constructed notion of the Bulgarian "situation" to quickly shatter.

Examining oplakvane through the methodological and theoretical frameworks of Ethnography of Communication and "terms for talk" provides a deeper understanding of the locally existing social relations, the cultural landscape, and the various ways the individual is imagined within it. Findings provide insight into the complexities of utilizing the term oplakvane as conflicted and contextually bound within the historical context of Ottoman and post-socialist struggles. Through ethnographic examination of the discourses available as cultural resources within the larger Bulgarian interactional terrain, I offer a way of re-seeing a previously unidentified way of speaking. Presently situated within the communicative shadows, oplakvane is not given the necessary thought, or is even dismissed as "social pessimism." Recognizing this communication practice would draw attention away from the reality it employs, and shift focus toward the participants as somewhat active members in the construction and maintenance of this reality. 
Here, we see a clear example of discourse as the starting point of understanding identity and social realities. The participants evoke and creatively manage this discourse as a resource to perform the cultural and communal function, as it is imbued with and shaped by the voices of our past. This approach of merging and understanding communication culturally allows for the comprehension of "social pessimism" in Bulgaria, and highlights the importance of nuanced ethnographic work within Eastern European, in order to gain a deeper understanding of the role of the larger post-socialist context as culturally managed in everyday lives. This work would provide a different, and thicker description of the ways historical contexts have long-lasting implications for local cultural conceptualizations of identity, agency, and social and political action via social interaction. 


\section{References}

Alicke, M. D., J. C. Braun, J. E. Glor, M. L. Klotz, J. Magee, H. Sederholm; \& Siegel, R. (1992). Complaining behavior in social interaction. Personality and Social Psychology Bulletin, $18,286-95$.

Annonymus. (2011). Comparing countries: The rich, the poor and Bulgaria. Money really can buy you happiness. The Economist. Retrieved from <http://www.economist.com/node/ 17722557>.

Au, N., Buhalis, D., \& Law, R. (2014). Online complaining behavior in mainland China hotels: The perception of Chinese and non-Chinese customers. International Journal of Hospitality \& Tourism Administration, 15, 248-274.

Baker, T. L., Meyer, T., \& Chebat, J. C. (2011). Cultural impacts on felt and expressed emotions and third party complaint relationships. Journal of Business Research. doi:10.1016/j.jbusres.2011.06.006

Baxter, L. (1993). "Talking things through" and "putting it in writing”: Two codes of communication in an academic institution. Journal of Applied Communication Research, $21,313-326$.

Boromisza-Habashi, D. (2013). Speaking Hatefully: Culture, Communication, and Political Action in Hungary. University Park, PA: Pennsylvania State University Press.

Carbaugh, D. (1989). Fifty terms for talk: A cross-cultural study. International And Intercultural Communication Annual, 13, 93-120.

Carbaugh, D. (1995). The ethnographic communication theory of Philipsen and associates. In 
Cushman D., \& Kovacic, B. (Eds.), Watershed traditions in communication (pp. 269297), Albany, NY: SUNY Press.

Carbaugh, D. (1999). “Just listen": "Listening” and landscape among the Blackfeet. Western Journal of Communication, 63(3), 250-270.

Carbaugh, D. (2007). Cultural discourse analysis: Communication practices and intercultural encounters. Journal of Intercultural Communication Research, 36(3), 167-182.

Carbaugh, D. (2010). Resituating cultural studies in communication: Cultural discourse analysis. In C., Baraldi, A., Borsari, \& A. Carli (Eds.). Hybrids, differences, visions: On the study of culture. Aurora, Colorado: The John Davies Group.

Carbaugh, D. (2017). The Handbook of Communication in Cross-Cultural Perspective. New York: Taylor \& Francis/Routledge International Communication Association.

Carbaugh, D. \& Hastings, S. (1992). A role for communication theory in ethnography and cultural analysis. Communication Theory, 2(2), 156-165.

Chaudhary, A. H. (2017). Complaint behavior of mothers and daughters in Pakistan: Transmission and differences between generations. Social Behavior \& Personality: an international journal, 45(10), 1723-1734.

Chebat, J. C., Kerzazi, L., \& Zourrig, H. (2010). Impact of culture on dissatisfied customers: An empirical study. City, Culture and Society, 1(1), 37-44.

Covarrubias, P. (2017). Respeto [respect] in disrespect: Clashing cultural themes within Mexican immigration discourses. In D. Carbaugh (Ed.). Handbook of communication in crosscultural perspective. International Communication Association Handbook series. New York \& London: Routledge.

Craig, R. T. (1999). Communication theory as a field. Communication Theory, 9, 119-161. 
Dori-Hacohen, G. (2017). Israeli online political commenting: Tokbek [talk-back] in between griping and hate-speech. In D. Carbaugh (Ed.). Handbook of communication in crosscultural perspective. International Communication Association Handbook series. New York \& London: Routledge.

Garrett, D. E., \& Meyers, R. A. (1996). Verbal communication between complaining consumers and company service representatives. Journal of Consumer Affairs, 30(2), 444-476.

Hall, B. J. \& Noguchi, M. (1995). Engaging in "kenson": An extended case study of one form of common sense. Human Relations, 48, 1129-1147.

Hymes, D. (1962). The ethnography of speaking. In T. Gladwin and W. Sturtevant (Eds.). Anthropology and human behavior. Washington, DC: Anthropological Society of Washington.

Jaworski, A., Coupland, N., \& Galasinki, D. (Eds.). (2004). Metalanguage: Social and Ideological Perspectives. Berlin, Germany: Mouton de Greuter.

Katriel, T. (1985). 'Griping' as a verbal ritual in some Israeli discourse. In M. Daseal (Ed.). Dialogue (pp. 367-381). John Bemjamins Publishing Company.

Katriel, T. (1986). Talking straight: "Dugri" speech in Israeil Sabra culture. New York: Cambridge University Press.

Katriel, T. (2004). Dialogic moments: From soul talks to talk radio in Israeli culture. Detroit, MI: Wayne State University Press.

Kowalski, R.M. (1996). Complaints and complaining: Functions, antecedents, and consequences. Psychological Bulletin, 119, 179-96.

Krastev, I. et al. (2004). Optimistic theory about the pessimism of the transition. Association 
Global Bulgarian Initiative. Retrieved from < http://www.clssofia.org/en/papers/optimistic-theory-about-the-pessimism-of-the-transition-40.html>.

Lee, E. L., \& Hall, B. (2009). Thou Soo and Aih Auan: Communicating dissatisfaction in a Chinese Malaysian community. Research on Language \& Social Interaction, 42(2), $116-134$.

Philipsen, G. (1992). Speaking culturally. Albany, NY: State University of New York Press.

Philipsen, G. (2002). Cultural communication. In W., Gudykunst, \& B. Moody (Eds.). Handbook of international and intercultural communication. Sage.

Philipsen, G. (2017). Epilogue. In D. Carbaugh (Ed.). The Handbook of Communication in Cross-Cultural Perspective. New York: Taylor \& Francis/Routledge International Communication Association.

Sotirova, N. (2017). Oplakvane in Bulgarian discourse. In D. Carbaugh (Ed.). The Handbook of Communication in Cross-Cultural Perspective (pp. 55-64). New York: Taylor \& Francis/Routledge International Communication Association.

Sotirova, N. (in press). The "Bulgarian situation": Constructing the myth of a "national mentality" in Bulgarian discourse and its effect on agency. Journal of Balkan and Near Eastern Studies.

Szymkow, A., B. Wojciszke, \& W. Baryla (2003). Psychologiczne funkcje narzekania [Psychological functions of complaining]. Czasopismo Psychologiczne, 9, 47-64.

Traikova, G. (Producer). (2012, March). bTV The Reporters. (Television broadcasr). Sofia, Bulgaria: bTV. Available from http://www.btv.bg/shows/btvreporterite/.

Trifonov, S. (2017). Twenty-five years of democracy, twenty-five years of social protest: The 
role of the carnivalesque in Bulgaria's 2013 antigovernment protests. Journal of International and Intercultural Communication, 10(3), 237-254.

Verdery, K. (1996). What was socialism, and what comes next? Princeton, New Jersey: Princeton University Press.

Wierzbicka, A. (1997). Understanding Cultures Through Their Key Words: English, Russian, Polish, German, Japanese. New York: Oxford University Press.

Winchatz, M. (2017). Jammern [whining] as a German way of speaking. In Carbaugh, D. (Ed.). Handbook of communication in cross-cultural perspective. International Communication Association Handbook series. New York \& London: Routledge.

Wojciszke, B. (2004/2005). The negative social world: The Polish culture of complaining. International Journal of Sociology, 34(4), 38-59. 
Table 1.

Bulgarian and English excerpts

1

Недоволство от неработеща система, липса на работа, неефективни държавни

структури и организации, бурокрация. Абдикацията на държавата от ежедневните

проблеми на хората. Няма изход от ситуацията.

Dissatisfaction with the non-working system, lack of jobs, ineffective state structures and

organization, bureaucracy. The abdication of the state from the everyday problems of

people. There's no way out of this situation.

2

Вчера се оплаках на моята приятелка, За постьпка на мъжа ми, която ме ядоса.

Тя ми каза да не се ядосвам и на свой ред се оплака от своя.

Yesterday I se oplakah to my friend, about something my husband did that made me angry. She told me not to get angry, and herself se oplaka from her husband.

Моя приятелка, която има същите проблеми със

свекърва си, така че в отговор на моето оплакване се оплака от нейната свекърва.

My friend, has the same problems with her mother in law

so in response to my oplakvane, se oplaka herself from her mother in law.

3

Много, ама много плачем - все другите са ни виновни, все нещо не ни е наред... Защо

- може би е остатьк от старата система, в която не се работеше качествено,

крадеше кой както може и нямаше никаква отговорност за нищо. И сега когато

трябва да учиш и работиш здраво, за да постигнеш нещо - е много тегаво.

We cry a lot, really a lot - it's always somebody else's fault, there is always something

wrong... Why - maybe it is a leftover from the old system, in which people did not work

well, everyone was stealing anything they could and had no responsibility for

anything. And now when you have to study and work hard to achieve anything - it is

very hard.

4

От всичко - от лош живот, от времето, от началника, от женат/мъжа, от

много работата, от липса на работа, абе от всичко. Когато си по природа

“оплаквач” винаги си намираш нещо за оплакване

[Bulgarians se oplakvat] from everything - bad life, from the weather, from the boss, from the wife/husband, from too much work, from lack of work, well from everything. When it is your nature to be a oplakvach [who se oplakva], you always find something for oplakvane 
Като улица без изход. Няма сила, която да накара избраните от нас

управляващи да мислят повече за това, което ще дадат, отколкото за това,

могат да вземат от държавата и народа. голямата простотия на българина.

Like a street with no exit. There is no force, that can make those in power chosen by us

Think more about what they give, rather than what they can take from the state and the

people. [The Bulgarian situation is t] he big stupidity of the Bulgarian people.

\section{6}

Плачевно, трагично, с никаква перспектива за подобрение.

Решението - атомна бомба.

Mournful, tragic, with no perspective to get better.

The solution - atomic bomb.

7

Njma znachenie, njma znachenie, ne mu puka! I vika "goljma rabota. Tova e ulica, she parkiram kadeto si iskam."

[B] ut it doesn't matter, doesn't matter, he doesn't care! And [he] says, "big deal. This is a street. I will park wherever I want."

8

B: njma, trjbva da ti kaga che t'va ah mladite trjbva da da da napuskat taj dargava.

G: ah (agreeing)

B: ne trjbva tuka

G: ma absolutno be, ma to njma za k'vo da sedi be*! [* dialectical particle]

B: there isn't, I have to tell you that this ah young people should should should

leave this state.

G: ah (agreeing)

B: they shouldn't [stay] here

G: but absolutely be*, but there is nothing to stay [here] for be*! 